Nevşehir Bilim ve Teknoloji Dergisi TARGíd Özel Sayı 19-31 2016

DOI: 10.17100/nevbiltek.210955

URL: http://dx.doi.org/10.17100/nevbiltek.210955

\title{
Armutlu Yöresinde Yetiştirilen Zeytinliklerde Verim ile Bazı Toprak Özellikleri
}

\section{Arasındaki İlișkinin Belirlenmesi}

\author{
Erdinç Uysal ${ }^{1, *}$, Barış Albayrak ${ }^{1}$, Fatih Kayalı ${ }^{2}$, Ahmet Karakoç², \\ Mustafa Bıyıklı ${ }^{1}$, Özlem Bengü Daş ${ }^{1}$ \\ ${ }^{1}$ Atatürk Bahçe Kültürleri Merkez Araştırma Enstitüsü, Toprak ve Su Kaynakları Bölümü, Yalova \\ ${ }^{2}$ Il Glda Tarım ve Hayvancllı Müdürlüğ̈̈, Yalova
}

Öz

Bu çalışma Gemlik çeşidi sofralık zeytin yetiştiriciliğinin yoğun olarak yapıldığı Yalova ili Armutlu ilçesinde toprakların bazı fiziksel ve kimyasal özelliklerini belirlemek amacıyla yürütülmüştür. 97 adet zeytin bahçesinden alınan toprak örneği çalışmanın materyalini oluşturmuştur. Alınan toprak örneklerinde bünye, pH, EC, kireç, organik madde, alınabilir fosfor ve değişebilir potasyum analizleri yapılmıştır.

Analizler sonucunda genel olarak toprak örneklerinin tınlı ve killi tınlı bünyede, kireç içeriklerinin çok düşük, toprak reaksiyonunun nötr ve asit karakterli oldukları görülmüştür. Organik madde ve alınabilir fosfor miktarları ise düşükten yüksek seviyeye kadar değişen oranlarda bulunmuştur. Zeytin bahçesi topraklarının değişebilir potasyum içerikleri ise çoğunlukla düşük ve çok düşük seviyelerde bulunmuştur. Toprak özellikleri ve elde edilen verim değerleri arasında yapılan korelasyon hesaplamaları sonucunda verim değerleri ile ağaç yaşı, toprakta elektriki iletkenlik, kireç, alınabilir fosfor ve değişebilir potasyum içerikleri arasında önemli ve pozitif yönlü ilişkiler bulunmuştur.

Anahtar Kelimeler: Zeytin, Gemlik Çeşidi, Verim, Toprak Verimliliăi

\section{Determination of the Relationship Between Yield and Some Soil Properties of Olive Grove Cultivated in Armutlu}

Abstract

This experiment was carried out to determine some physical and chemical properties of soils in which Gemlik olive cultivar is grown in Armutlu, Yalova region. The soil samples taken from 97 olive gardens consist the material of study. Texture, $\mathrm{pH}$, EC, lime, organic matter, available phosphorus and exchangeable potassium analyses were done to the soil samples.

As a consequence of the analyses; it was seen that the soil samples were usually loam sand clay loam textured, with low lime content and neutral and acid characterized soil reaction. The amounts of organic matter and available phosphorus were found at differentiating level either high or in low levels. The exchangeable potassium content of olive garden soil is mostly found at low and very-low levels. As a result of correlation calculations done between the soil characteristics and the obtained yield values; significant and positive relations were found between the yield values and age of tree, electrical conductivity in the soil, lime, available phosphorus and exchangeable potassium contents.

Keywords: Olive, Gemlik Cultivar, Yield, Soil Fertility,

"e-mail: erdincuysal@hotmail.com 


\section{Giriş}

Zeytin başta Akdeniz ülkeleri olmak üzere Asya, Amerika ve Kuzey Afrika ülkelerinin tarımında ekonomik ağırlığı bulunan önemli bir kültür bitkisidir. Çok yıllık olan ve sürekli yeşil kalan zeytin ağacının meyvesi sofralık olarak değerlendirildiği gibi yemeklik kaliteli sıvı yağ hammaddesi olarak da değerlendirilir. Türkiye, önemli zeytin üreticisi ülkelerden birisi konumundadır (Şekil1).

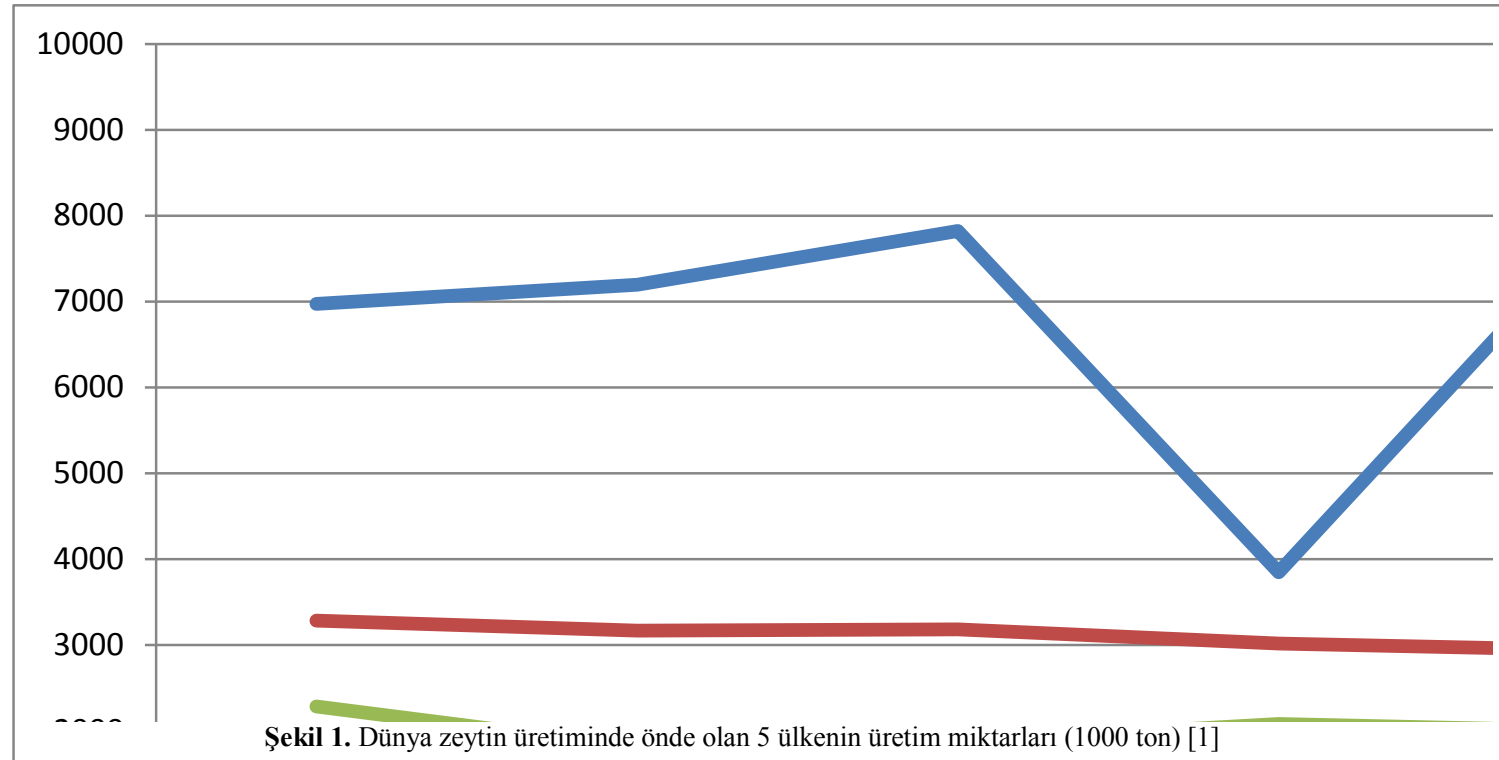

Ülkemiz zeytin yetiştiriciliği Ege Bölgesinde yoğunlaşmış olup bunu Akdeniz ve Marmara Bölgeleri izlemektedir. Son yıllarda Kuzeydoğu ve Güneydoğu tarım bölgelerimizde de dikkate değer düzeyde yetiştiricilik yapılmaya başlanılmıştır. 2014 yılı verilerine göre toplam zeytin üretimimizin \% 25 'ini sofralık, \% 75 ini de yağıtk üretim oluşturmaktadır (Şekil 2).

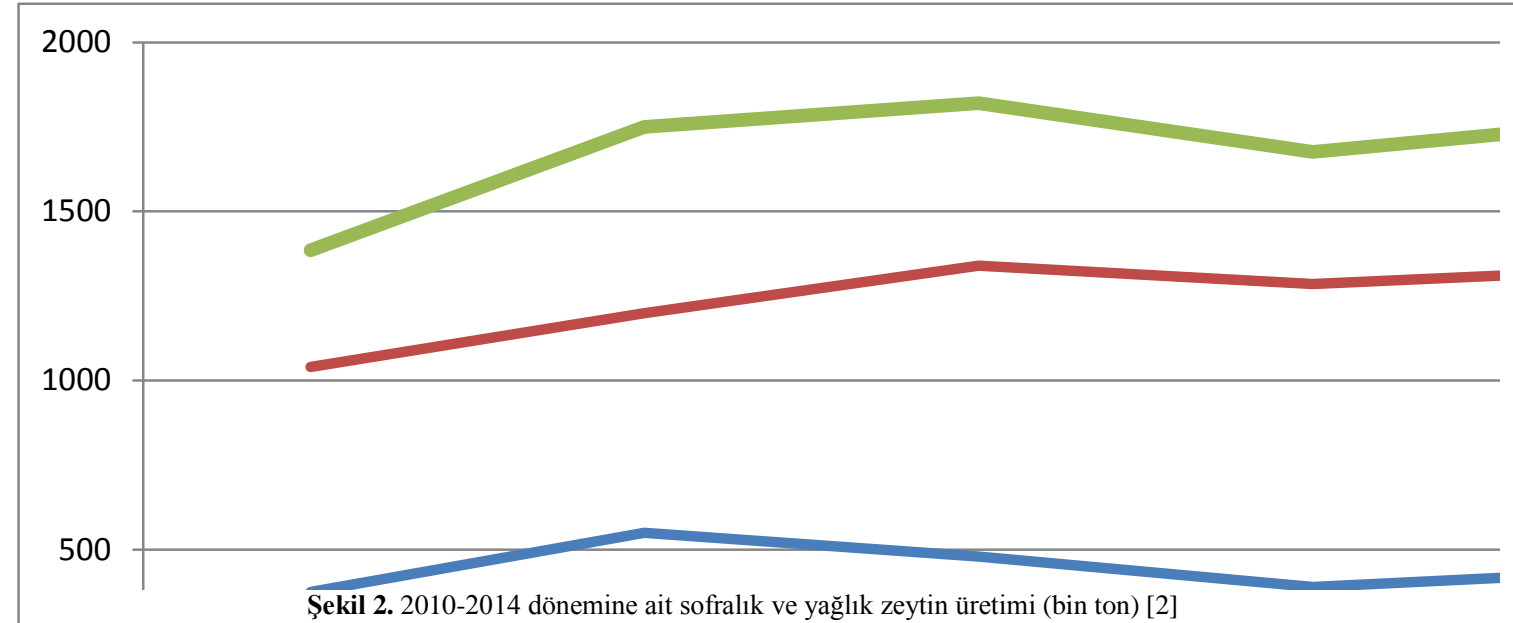

Şekil 2. 2010-2014 dönemine ait sofralık ve yağlık zeytin üretimi (bin ton) [2]

Zeytin genellikle kireçli, kumlu tınlı ve taşlı iyi havalanan topraklarda iyi yetişir. Taban suyu seviyesinin yüksekliğine karşı duyarlıdır. Yüksek taban suyu kök çürüklüğüne neden olur. Ağır topraklarda gelişmesi çok zayıftır [3]. 
Değişik yaştaki Memecik zeytin ağaçlarının budama atıkları ve zeytin ürünü ile topraktan kaldırdıkları azot, fosfor ve potasyum miktarlarını araştıran Dikmelik, $1 \mathrm{~kg}$ budama artığı ile topraktan $5.4 \mathrm{~g} \mathrm{~N}, 0.9 \mathrm{~g} \mathrm{P}_{2} \mathrm{O}_{5}$ ve $3.2 \mathrm{~g} \mathrm{~K}_{2} \mathrm{O}$ kaldırdığını saptamıştır [4]. Araştırıcı $1 \mathrm{~kg}$ ürün ile ortalama $4.1 \mathrm{~g} \mathrm{~N}, 1.4$ g $\mathrm{P}_{2} \mathrm{O}_{5}$ ve 10 g K${ }_{2} \mathrm{O}$ kaldırıldığını belirlemiştir. Ürün ile kaldırılan $\mathrm{N} \mathrm{P}_{2} \mathrm{O}_{5}: \mathrm{K}_{2} \mathrm{O}$ oranı 1.0:0.35:2.4 iken, budama artıklarılla kaldırılan miktar 1.0:0.24:1.4 şeklindedir.

İsrail'de alt1 yıl süre ile yürütülen bir gübreleme denemesinde azot ve potasyumun değişik dozlarda ayrı ayrı ve kombine olarak uygulanması sonucunda azotun yaprak ve ürün üzerinde olumlu etki yaptığı ve bu etkinin potasyum ile birlikte daha da arttığı tespit edilmiştir [5].

Gemlik yöresinde yetiştirilen zeytinlerin beslenme durumlarını belirlemek amacıyla yapılan çalışma sonuçlarına göre; toprak örnekleri tın ve killi tın bünyeye sahiptir. Kireç içerikleri düşük ve orta olan topraklar nötr ve hafif alkalin karakterli bulunmuştur. Organik madde miktarları genelde orta düzeyde bulunan zeytin bahçesi topraklarının alınabilir fosfor ve değişebilir potasyum içeriklerinin ise düşükten yüksek seviyeye kadar değişen miktarlarda olduğu bildirilmiştir [6].

Aydın yöresinde yapılan bir çalışma sonuçlarına göre, yöre zeytinlerine ait toprakların genelde kumlu tınlı ve tınlı kumlu bünyede, kireç ve pH yönünden değişken olduğu, tuzluluk sorunu bulunmadığ ancak zeytin topraklarının \% 78'inin organik maddece yoksul olduğu saptanmıştır [7].

Sofralık zeytin yetiştiriciliğinin yoğun olarak yapıldığı Bursa ili Orhangazi ilçesinde toprakların bazı verimlilik özelliklerini belirlemek amacıyla yürütülen çalışmada zeytin bahçelerinden alınan 312 adet toprak örneği analiz edilmiştir. Elde edilen bulgulara göre; toprak örnekleri genel olarak tın ve killi tın bünyeli, kireç içerikleri genellikle düşük, toprak reaksiyonu nötr ve hafif alkali karakterli, organik madde içerikleri orta ve yüksek düzeyde bulunmuştur. Zeytin topraklarının alınabilir fosfor içerikleri yeterli ve yüksek değişebilir potasyum içerikleri ise düşükten yüksek seviyeye kadar değişen oranlarda olduğu belirlenmiştir [8].

Bursa yöresinde yetiştirilen Gemlik çeşidi zeytin ağaçlarının makro ve mikro besin elementlerinin mevsimsel değişimlerinin incelendiği bir çalışmada ve en uygun yaprak örneği alma zamanı Ocak ve Şubat ayları olarak belirlenmiştir [9].

Ürün çağına gelmiş ağaçlarda ağaç başına 400-500 g N, 400-500 g $\mathrm{P}_{2} \mathrm{O}_{5}$ ve $500 \mathrm{~g} \mathrm{~K}_{2} \mathrm{O}$ uygulanabileceği önerilirken [10], bir başka çalışmada ise 25-50 kg/ağaç ürün veren ağaçlara 700-800 g N, 700-800 g $\mathrm{P}_{2} \mathrm{O}_{5}$ ve 750-1050 g K2 $\mathrm{O}$ uygulanması önerilmektedir [11].

Artan miktarlarda azotlu gübre uygulamasının zeytinde verim ve kaliteye etkisini incelemek amacı ile yapılan çalışmada, Memecik zeytin çeşidinde, beslenme durumuna göre $800 \mathrm{~g} /$ ağaç $\mathrm{N}$ düzeyine kadar azot uygulaması yapılabileceği sonucuna varılmıştır [12].

$\mathrm{Bu}$ çalışmanın amacı çoğunlukla sofralık olarak tüketilen Gemlik çeşidi zeytinliklerin yetiştiriciliğinin yoğun olduğu Yalova ili Armutlu ilçesinde zeytin bahçe topraklarının bazı fiziksel ve kimyasal özelliklerinin incelenmesi, mevcut beslenme sorunlarının ortaya konulması ve bunun sonucunda toprak analiz sonuçlarına dayalı olarak bahçelerin gübreleme programlarının oluşturulabilmesinin sağlanmasıdır. 


\section{Materyal ve Metot}

Yalova ilinde zeytin yetiştiriciliğinin yoğun olduğu Armutlu ilçesinden 2011 yılı Ekim ay1 içerisinde ve 0-30 cm'lik üst toprak derinliğinden alınarak Atatürk Bahçe Kültürleri Merkez Araştırma Enstitüsü Toprak ve Su Kaynakları Bölümü Laboratuvarına getirilen 97 adet toprak örneği materyal olarak kullanılmıştır. Toprak örnekleri Armutlu ilçe merkezi ve zeytin yetiştiriciliği yapılan köylerinden alınmıştır. Toprak örneklerinin alındığı bölge toprak grubu açısından kireçsiz kahverengi orman toprakları sınıfında yer almaktadır [13]. Toprak örnekleri alınırken bahçe sahipleriyle görüşülerek ortalama verim ve bahçelere ait bazı bilgiler de alınmıştır.

Toprak örnekleri alındıktan sonra gerekli aşamalardan geçirilerek analize hazır hale getirilmiş [14], bünye, doygunluk yüzdesine göre belirlenmiş [15], toprak pH s1, 1:2.5 toprak -su karışımında cam elektrotlu pH metre ile [16], elektriki geçirgenlik aynı karışımda iletkenlik ölçer ile ölçülmüştür. Kireç; Scheibler kalsimetresi ile [17], \% Organik madde; Modifiye Walkley-Black yöntemine göre [18], alınabilir fosfor, 0.5 M sodyum bikarbonat (pH: 8.5) ile ekstraksiyon yöntemiyle [19], değişebilir potasyum, $1 \mathrm{~N}$ Amonyum Asetat (pH:7.0) ekstraksiyonu ile [20] belirlenmiştir.

\section{Bulgular ve Tartışma}

Toprak örneklerinin bazı fiziksel ve kimyasal özelliklerine ait değerlerin sınıflandırmalarında kullanılan referanslar ve sınır değerleri ile çalışmada elde edilen sonuçların bu değerlere göre dağılımını gösteren sonuçlar Tablo 1'de verilmiştir. Armutlu yöresinde zeytin yetiştirilen 97 adet bahçeye ait ağaç yaşları, ağaç başı verim ve alınan toprak örneklerinin bazı fiziksel ve kimyasal özelliklerine ait analiz sonuçları ve bu sonuçlara ilişkin en küçük, en büyük ve ortalama değerler Tablo 2'de gösterilmiştir.

Toprak bünyelerini belirlemek amacıyla saturasyon yüzdesine göre yapılan sınıflandırmada [15] toprak örneklerinden, \% 87.6'sının killi tın ve tın bünyeli, \% 12.4'ünün ise ise kumlu bünyeli oldukları anlaşılmıştır. Aynı amaçla yapılan farklı bir çalışmada Gemlik yöresinde yetiştirilen Gemlik çeşidi zeytinlerin yetiştiği alanlara ait incelenen toprakların genel olarak tın ve killi tın bünyeye sahip oldukları belirlenmiş̧ir [6]. Kapıdağ Yarımadasındaki zeytin alanlarından alınan 571 adet toprak örneğinde yapılmış olan analizlerde toprakların büyük ölçüde tın ve killi tın bünyede oldukları tespit edilmiştir [21]. Çalışma sonucunda örneklerin 395 tanesi (\% 69.2) tın ve 163 tanesi (\%28.5) ise killi tın tekstüre sahip bulunmuştur. Toprak profilinin homojen olması kaydı ile kumlu tınlı, tınlı, tınl1-kumlu, killi-tınlı topraklar zeytin plantasyonları için uygundur [3]. Kumlu tından killi tına kadar değişik bünyeli toprakların zeytin yetiştiriciliği için uygun olduğu değerlendirmesine göre [22] ve zeytin için yapılan benzer çalışmalarda elde edilen sonuçlara göre alınan örneklerin büyük çoğunluğunun toprak bünyesi açısından zeytin yetiştiriciliğine uygun olduğu görülmektedir. 
Tablo 1. Toprak örneklerinin bazı fiziksel ve kimyasal özelliklerine göre sınıflandırılması

\begin{tabular}{|c|c|c|c|}
\hline Toprak Özelliği & Sınır Değeri & Değerlendirme & $\%$ \\
\hline \multirow{4}{*}{ Saturasyon (\%, Gedikoğlu 1990) } & $<30$ & Kumlu & 12.4 \\
\hline & $30-50$ & Tinlı & 81.4 \\
\hline & $51-70$ & Killi Tınlı & 6.2 \\
\hline & $71-110$ & Killi & 0 \\
\hline \multirow{5}{*}{ pH (Eyüpoğlu 1999) } & $4.5-5.5$ & Orta Asit & 10.3 \\
\hline & $5.6-6.5$ & Hafif Asit & 53.6 \\
\hline & $6.6-7.5$ & Nötr & 34.0 \\
\hline & 7.6-8.5 & Hafif Alkali & 0 \\
\hline & $>8.5$ & Kuvvetli Alkali & 0 \\
\hline \multirow{5}{*}{$\mathrm{EC}_{25}$ (ds m ${ }^{-1}$, Dellavalle 1992) } & $<0.40$ & Tuzsuz & 95.9 \\
\hline & $0.40-0.80$ & Hafif Tuzlu & 2.10 \\
\hline & $0.81-1.20$ & Orta Tuzlu & 1.0 \\
\hline & $1.21-1.60$ & Tuzlu & 1.0 \\
\hline & $1.61-3.20$ & Yüksek tuzlu & 0 \\
\hline \multirow{5}{*}{$\mathrm{CaCO}_{3}(\%$, Çağlar 1958) } & $<1.0$ & Çok Düşük & 99.0 \\
\hline & $1.0-5.0$ & Düşük & 0 \\
\hline & $5.1-15.0$ & Orta & 0 \\
\hline & $15.1-25.0$ & Yüksek & 1.0 \\
\hline & $>25.0$ & Çok Yüksek & 0 \\
\hline \multirow{5}{*}{ Organik Madde (\%, Anonim 1985) } & $<1.0$ & Çok Düşük & 0 \\
\hline & $1.0-2.0$ & Düşük & 28.9 \\
\hline & $2.1-3.0$ & Orta & 30.9 \\
\hline & $3.1-4.0$ & Yüksek & 27.8 \\
\hline & $>4.0$ & Çok Yüksek & 12.4 \\
\hline \multirow{4}{*}{ Alınabilir P (mg kg ${ }^{-1}$, Olsen ve ark. 1954) } & $<3.0$ & Çok Düşük & 7.2 \\
\hline & $3.0-7.0$ & Düşük & 22.7 \\
\hline & $7.1-20.0$ & Orta & 37.1 \\
\hline & $>20.0$ & Yüksek & 33.0 \\
\hline \multirow{6}{*}{ Değişebilir K (me $100 \mathrm{~g}^{-1}$, Pizer 1967) } & $<0.255$ & Çok Düşük & 59.8 \\
\hline & $0.256-0.385$ & Düşük & 23.7 \\
\hline & $0.386-0.510$ & Orta & 11.3 \\
\hline & $0.511-0.640$ & İyi & 2.1 \\
\hline & $0.641-0.820$ & Yüksek & 2.1 \\
\hline & $>0.820$ & Cok Yüksek & 1.0 \\
\hline
\end{tabular}

Topraklarda pH 4.5 - 7.6 arasında değişmektedir. Yapılan değerlendirme [23] sonucunda toprakların, \% 10.3’ü orta asit, \% 53.6'sı hafif asit ve \% 34'ü nötr reaksiyondadır. Buna göre toprakların büyük çoğunluğu asit karakterde bulunmuştur. Zeytin yetiştirilen farklı alanlarda yapılan benzer çalışmalarda zeytinlerin toprak reaksiyonu açısından geniş bir aralıkta yetişebildiği görülmüştür. Kapıdağ yarımadası zeytinliklerinden alınan toprakların toprak reaksiyonu bakımından büyük kısmının (\%48.3) hafif asit karakterdeki topraklardan oluştuğu belirlenmiştir [21]. Orhangazi yöresinde yetiştirilen zeytinlerden alınmış 312 adet toprak örneği ile yapılmış bir çalışmada toprakların pH'ları 4.4-8.6 arasında değişim gösterirken büyük çoğunluğu (\% 59) hafif alkalin karakterde bulunmuştur [8]. İçel yöresi 
Uysal E., Albayrak B., Kayalı F., Karakoç A., Bıyıklı M., Bengü Daş Ö.

zeytinliklerinin beslenme durumlarını belirlemek amacıyla, bölgeden alınmış 50 adet toprak örneğiyle yapılan çalışma sonucunda ise toprak reaksiyonlarının 7.0-7.9 arasında değiştiği ve \% 94'ünün hafif alkalin karakterde olduğu bildirilmiştir [24]. Zeytin bitkisi 5.0 - 8.5 arasındaki pH aralıklarına uyum gösterse de, $6.5-8.5 \mathrm{pH}$ aralıklarında daha iyi gelişme göstermektedir [21].

Tablo 2. Zeytinliklere ait bazı bilgiler ile toprak analiz sonuçları ve sonuçlara ait en küçük, en büyük ve ortalama değerler

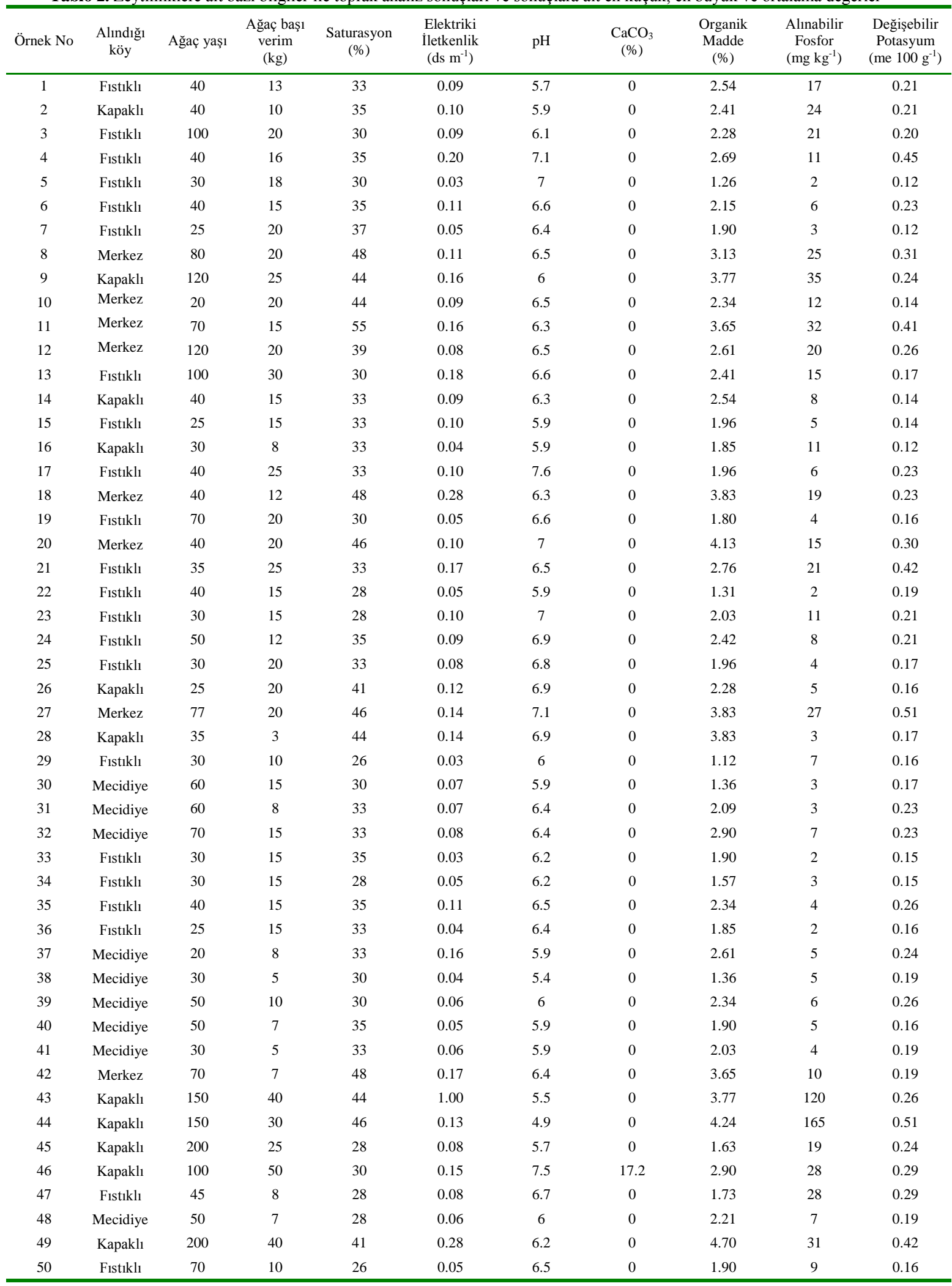


Tablo 2. Devam

\begin{tabular}{|c|c|c|c|c|c|c|c|c|c|c|}
\hline Örnek No & $\begin{array}{l}\text { Alındığ } 1 \\
\text { köy }\end{array}$ & $\begin{array}{l}\text { Ağaç } \\
\text { yaş1 }\end{array}$ & $\begin{array}{l}\text { Ağaç başı } \\
\text { verim } \\
(\mathrm{kg})\end{array}$ & $\begin{array}{c}\text { Saturasyon } \\
(\%)\end{array}$ & $\begin{array}{c}\text { Elektriki } \\
\text { İletkenlik } \\
\left(\mathrm{ds} \mathrm{m}^{-1}\right)\end{array}$ & $\mathrm{pH}$ & $\begin{array}{c}\mathrm{CaCO}_{3} \\
(\%)\end{array}$ & $\begin{array}{c}\text { Organik } \\
\text { Madde } \\
\text { (\%) }\end{array}$ & $\begin{array}{l}\text { Alınabilir } \\
\text { Fosfor } \\
\left(\mathrm{mg} \mathrm{kg}^{-1}\right)\end{array}$ & $\begin{array}{c}\text { Değişebilir } \\
\text { Potasyum } \\
\left(\text { me } 100 \mathrm{~g}^{-1}\right)\end{array}$ \\
\hline 51 & Merkez & 40 & 20 & 46 & 0.13 & 6.6 & 0 & 3.24 & 18 & 0.30 \\
\hline 52 & Merkez & 35 & 15 & 59 & 0.20 & 6.5 & 0 & 3.95 & 35 & 0.35 \\
\hline 53 & Merkez & 120 & 15 & 46 & 0.18 & 7.3 & 0 & 3.65 & 33 & 0.67 \\
\hline 54 & Merkez & 40 & 15 & 41 & 0.08 & 6.3 & 0 & 3.83 & 25 & 0.28 \\
\hline 55 & Merkez & 70 & 35 & 37 & 0.11 & 6.7 & 0 & 2.41 & 16 & 0.42 \\
\hline 56 & Merkez & 120 & 15 & 30 & 0.07 & 6 & 0 & 1.36 & 8 & 0.21 \\
\hline 57 & Merkez & 40 & 8 & 39 & 0.20 & 7.1 & 0 & 3.47 & 8 & 0.17 \\
\hline 58 & Merkez & 50 & 10 & 46 & 0.08 & 6 & 0 & 2.47 & 8 & 0.21 \\
\hline 59 & Merkez & 40 & 2 & 39 & 0.10 & 6.2 & 0 & 4.24 & 20 & 0.30 \\
\hline 60 & Merkez & 50 & 5 & 44 & 0.25 & 6.5 & 0 & 3.59 & 30 & 0.67 \\
\hline 61 & Merkez & 100 & 6 & 70 & 0.18 & 7.6 & 0 & 3.47 & 22 & 0.26 \\
\hline 62 & Merkez & 70 & 25 & 46 & 0.27 & 7.2 & 0 & 2.98 & 9 & 0.39 \\
\hline 63 & Merkez & 100 & 10 & 52 & 0.27 & 7.1 & 0 & 3.42 & 36 & 0.28 \\
\hline 64 & Merkez & 30 & 13 & 41 & 0.16 & 7.1 & 0 & 2.76 & 19 & 0.19 \\
\hline 65 & Merkez & 60 & 20 & 57 & 0.11 & 4.9 & 0 & 4.24 & 30 & 0.42 \\
\hline 66 & Fistıkl1 & 70 & 10 & 33 & 0.17 & 6.6 & 0 & 3.42 & 10 & 0.42 \\
\hline 67 & Fistıklı & 20 & 10 & 33 & 0.08 & 6.5 & 0 & 1.57 & 2 & 0.12 \\
\hline 68 & Merkez & 100 & 40 & 46 & 0.13 & 6.4 & 0 & 3.47 & 28 & 0.37 \\
\hline 69 & Merkez & 100 & 8 & 35 & 0.19 & 6.3 & 0 & 3.30 & 21 & 0.57 \\
\hline 70 & Fistiklı & 70 & 10 & 28 & 0.07 & 6.4 & 0 & 1.36 & 12 & 0.24 \\
\hline 71 & Merkez & 50 & 2 & 46 & 0.11 & 6.5 & 0 & 4.70 & 2 & 0.17 \\
\hline 72 & Merkez & 100 & 20 & 41 & 0.13 & 6.5 & 0 & 4.35 & 33 & 0.87 \\
\hline 73 & Merkez & 50 & 8 & 55 & 0.17 & 6.9 & 0 & 3.59 & 5 & 0.30 \\
\hline 74 & Kapaklı & 300 & 40 & 48 & 2.90 & 4.5 & 0 & 5.82 & 61 & 0.57 \\
\hline 75 & Merkez & 20 & 15 & 37 & 0.23 & 6.8 & 0 & 4.47 & 12 & 0.23 \\
\hline 76 & Merkez & 80 & 10 & 50 & 0.09 & 6.4 & 0 & 2.34 & 13 & 0.17 \\
\hline 77 & Kapaklı & 300 & 8 & 30 & 0.14 & 6.3 & 0 & 2.90 & 26 & 0.35 \\
\hline 78 & Merkez & 100 & 20 & 39 & 0.17 & 6.7 & 0 & 3.13 & 40 & 0.24 \\
\hline 79 & Kapaklı & 200 & 17 & 37 & 0.70 & 7.3 & 0 & 4.04 & 50 & 0.30 \\
\hline 80 & Merkez & 25 & 15 & 30 & 0.10 & 6.5 & 0 & 1.96 & 24 & 0.30 \\
\hline 81 & Kapaklı & 100 & 30 & 37 & 0.12 & 5.1 & 0 & 3.30 & 28 & 0.23 \\
\hline 82 & Merkez & 40 & 12 & 26 & 0.06 & 5.5 & 0 & 1.52 & 8 & 0.16 \\
\hline 83 & Fistıklı & 100 & 15 & 44 & 0.12 & 6.7 & 0 & 2.28 & 13 & 0.16 \\
\hline 84 & Kapaklı & 200 & 40 & 41 & 0.21 & 5.9 & 0 & 2.69 & 9 & 0.19 \\
\hline 85 & Fistıklı & 30 & 15 & 39 & 0.16 & 6 & 0 & 3.65 & 51 & 0.28 \\
\hline 86 & Merkez & 50 & 15 & 48 & 0.18 & 6.7 & 0 & 4.24 & 8 & 0.32 \\
\hline 87 & Fistıklı & 100 & 30 & 28 & 0.09 & 5.7 & 0 & 1.96 & 31 & 0.24 \\
\hline 88 & Fistıkli & 20 & 5 & 30 & 0.03 & 6.2 & 0 & 1.51 & 1 & 0.16 \\
\hline 89 & Kapaklı & 25 & 15 & 37 & 0.09 & 6.7 & 0 & 2.54 & 6 & 0.10 \\
\hline 90 & Kapaklı & 300 & 30 & 28 & 0.08 & 6.5 & 0 & 2.21 & 12 & 0.17 \\
\hline 91 & Merkez & 80 & 19 & 44 & 0.05 & 6.6 & 0 & 2.61 & 13 & 0.24 \\
\hline 92 & Kapaklı & 40 & 10 & 39 & 0.13 & 7.3 & 0 & 3.83 & 19 & 0.19 \\
\hline 93 & Kapaklı & 50 & 15 & 39 & 0.08 & 6.6 & 0 & 2.98 & 12 & 0.19 \\
\hline 94 & Kapaklı & 80 & 15 & 42 & 0.14 & 5.2 & 0 & 5.55 & 20 & 0.32 \\
\hline 95 & Kapaklı & 30 & 15 & 33 & 0.80 & 5.2 & 0 & 3.77 & 26 & 0.32 \\
\hline 96 & Kapaklı & 100 & 25 & 35 & 0.28 & 5.1 & 0 & 3.47 & 110 & 0.24 \\
\hline 97 & Merkez & 35 & 15 & 48 & 0.25 & 6.8 & 0 & 3.30 & 12 & 0.43 \\
\hline $\begin{array}{c}\text { En küçük } \\
\text { değer }\end{array}$ & & 20 & 2 & 26 & 0.03 & 4.5 & 0 & 1.12 & 2 & 0.11 \\
\hline $\begin{array}{l}\text { Ortalama } \\
\text { değer }\end{array}$ & & 71 & 17 & 38 & 0.17 & 6.4 & 0.18 & 2.83 & 19 & 0.27 \\
\hline $\begin{array}{c}\text { En büyük } \\
\text { değer }\end{array}$ & & 300 & 50 & 70 & 2.90 & 7.6 & 17.20 & 5.82 & 165 & 0.87 \\
\hline
\end{tabular}


Zeytinden yeterli verim alınabilmesi için toprak pH'sının 7-8 arasında olması istenir [22]. Zeytin ağacı hafif asit ve hafif alkali toprak pH'larında iyi gelişme gösterirken bunun dışındaki toprak pH'larında verimde azalma, element noksanlıkları ve kalitede bozulmalar görülmektedir. Özellikle pH değerinin $6.5^{\prime}$ 'in altında ve $8.0^{\prime}$ 'in üzerinde olduğu bölgelerde zeytin ağacı iyi beslenememektedir [25]. Toprak reaksiyonu bakımından Armutlu yarımadasından alınarak incelenen toprakların büyük kısmını asit karakterdeki topraklar oluşturmaktadır. Genel olarak 6.5-8.0 toprak pH'ları arasında daha iyi gelişme gösterdiği bildirilen zeytin için bölge toprak reaksiyonlarının istenilen düzeyin altında olduğu söylenebilir.

Elektriksel iletkenlik değerleri yönünden incelendiğinde [26] bahçelerden alınan toprakların yaklaşık \% 96'sı tuzsuz sınıfa girmiştir, bu nedenle bahçelerde herhangi bir tuzluluk problemi olmadığını söyleyebiliriz. Farklı bölgelerde yapılmış olan benzer çalışmaların sonucunda elde edilen bilgilerin birbirine benzediği görülmektedir. Buna göre Bursa ilinde [27], İçel yöresinde [24], Kapıdağ yarımadasında [21], Aydın yöresinde [7], İznik bölgesinde [28], incelenen zeytin bahçesi topraklarının tamamına yakınının tuzsuz sınıfa giren topraklardan oluştuğu bildirilmiştir.

İncelenen bahçe topraklarının, \% 28.9'u düşük, \% 30.9'u orta ve \% 40.2'si yüksek ve çok yüksek düzeyde [18] organik madde içermektedir. Türkiye toprakları genel olarak organik maddece yoksuldurlar. Yaklaşık \% 64'ü çok az ya da az miktarda organik madde içermektedir [29]. Aydın yöresinde zeytinde yapılan bir çalışmada organik madde bakımından yetersizlik oranını \% 78 olarak belirlenmiştir [7]. Sofralık zeytin yetiştiriciliğinin yoğun olarak yapıldığı Bursa ili Gemlik ilçesinde toprakların bazı verimlilik özelliklerini belirlemek amacıyla yürütülen çalışmada zeytin bahçelerinden alınan 128 adet toprak örneği analiz edilmiştir [6]. Elde edilen sonuçlara göre toprakların \% 22.7’sinin az ve çok az, \% 47.7'sinin orta ve \% 29.7'sinin yüksek ve çok yüksek düzeyde organik madde içerdiği ifade edilmiştir. Orhangazi ilçesinde yine sofralık Gemlik çeşidi zeytinlerle yapılan çalışmada toprakların \% 30.5'inde organik madde az veya çok az iken, \% 69.5'inde orta ve üzerinde çıkmıştır [8]. İznik bölgesinde bulunan zeytinliklerin toprak özelliklerini belirlemek amaciyla 154 bahçeden alınan toprak örneklerinin incelenmesi sonucunda bahçelerin \% 13'ünün az, \% 48.1'inin orta ve \% 38.9’unun yüksek ve çok yüksek düzeyde organik madde içerdiği görülmüştür [28]. Yapılan farklı çalışmalar incelendiğinde bölgeye yakın olan alanlarda zeytin bahçelerinin organik madde içeriklerinin bizim çalışmamızda da olduğu gibi genel olarak orta ve yüksek içeriklerde olduğu görülmektedir.

Araştırmaya konu topraklar kireç içerikleri açısından değerlendirildiğinde Tablo 2'den de anlaşılacağı üzere alınan toprakların bir tanesi haricinde kireç içermediği görülmüştür. Kireç bulunan tek topraktaki kirecin nedeninin yapılan kireçlemeden dolayı olduğu düşünülmektedir. Kapıdağ yarımadası zeytinliklerinin kireç içeriklerinin belirlendiği çalışmada incelenen toprakların \% 80'inin \% 1'den az kireç içerdiği, \% 19.1'inin ise \% 1-5 arasında kireç içeriğine sahip olduğu belirlenmiștir [21]. Bunun yanında daha uzak bir bölgede İçel yöresinde yetişen zeytinlerde yapılan başka bir çalışmada toprakların kireç içeriklerinin \% 1.8-66.3 arasında değişim gösterdiği ve \% 98'inin kireççe zengin olduğu ifade edilmiştir [24]. İznik ilçesinde zeytin yetiştirilen alanlarda yapılan inceleme de toprakların \% 70.12'sinin düşük ya da çok düşük kireç içerdiği saptanmıştır [28]. Bunun yanında \% 23.4'ü orta seviyede kireç içerirken \% 6.5'inde kireç yüksek düzeyde bulunmuştur. Zeytin genellikle yoksul toprakların varsıl bitkisi olarak bilinir, kireçli topraklarda gayet iyi gelişir [3]. Zeytin kireç bakımından geniş bir sınıra 
tolerans gösterir ve verimliliğinden bir şey kaybetmez [22]. Çalışma sonucunda Yarımadadaki zeytinliklerin genel itibariyle kireç içermediği ve düşük pH'lara sahip olduğu görülmüştür. Zeytin gerçekte geniş toprak reaksiyonunda yetişebilen, kirece tolerans gösteren ve kuraklığa dayanıklı bir bitkidir. Ancak, kaliteli ve bol ürün almak özel şartların karşılanmasını gerektirir [30 ve 31]. Bu nedenle bölgede bazı alanlarda toprak özelliklerini belirlemek koşuluyla ve kireçleme materyalinin özelliklerini de dikkate alarak, uygun miktarda kireçleme yapılması yararlı olabilir.

Alınabilir fosfor bakımından topraklar değerlendirildiğinde [19] fosfor içeriklerinin değişkenlik gösterdiği görülmektedir. Topraklar \% 29.9 oranında düşük ya da çok düşük fosfor içeriğine sahip bulunurken, \% 37.1 orta ve \% 33 oranında da yüksek düzeyde fosfor varlığı belirlenmiş̧tir. Bursa yöresinde yetiştirilen Gemlik çeşidi zeytin ağaçlarının makro ve mikro besin elementleri durumunu belirlemek amacıyla yapılan çalışmada toplanan yaprak örnekleri analiz edilmiş ve fosforun genellikle yeterli olduğu rapor edilmiştir [27]. Gemlik yöresinde zeytin bahçelerinde toprakların fosfor içeriklerinin belirlendiği çalışmanın sonuçlarına göre toprakların \% 21.9'u düşük yada çok düşük, \% 47.7'si orta düzeyde ve \% 30.5 ' $\mathrm{i}$ ise yüksek oranda fosfor içermiştir [6]. İçel ilinde yapılan inceleme de fosfor açısından toprakların \% 60'1 yetersiz bulunurken \% 40'ının yeterli olduğu belirtilmiştir [24]. Aydın yöresinde Memecik zeytin çeşidi ile yapılan çalışmada yaprak analiz sonuçlarına göre zeytinliklerin \% 62'sinde fosfor eksikliği görüldügü bildirilmiş̧ir [21]. Zeytinde fosfor gereksinimi azot ve potasyum kadar yüksek olmasa da bu ihtiyacın gübreleme ile karşılanması önemlidir [3]. Zeytin ürünü ve budama artıklarıyla topraktan kaldırılan besin maddesi oranları incelendiğinde 0.24 birim fosfora karşılık 1.0 birim azot, 1.4 birim potasyum kaldırılmaktadır [4]. Zeytinde fosforun öneminin anlatıldığı bir çalışmada, $40 \mathrm{~kg}$ ürün veren ağaçlara azami $420 \mathrm{~g} \mathrm{P}_{2} \mathrm{O}_{5}$ içeren fosforlu gübre verilmesi tavsiye edilmiştir [32]. Fosfor içeriklerindeki bu farkların, üreticilerin gübre uygulamalarıyla ilgili bir durum olduğu açıktır. Fosfor gübrelemesinde toprak analiz sonuçlarına göre hareket edilmesi büyük önem taşımaktadır.

Değişebilir potasyum içerikleri açısından çalışmada elde edilen sonuçlar 0.11 - 0.87 me $100 \mathrm{~g}^{-1}$ değerleri arasında değişiklik göstermiştir. Bu sonuçlara göre yapılan değerlendirme de [33] zeytin bahçelerinin \% 83.5'i düşük ve çok düşük, \% 13.4'ü orta ve iyi, \% 3.1'i yüksek ve çok yüksek düzeyde potasyum içermektedir. Farklı bölgelerde yapılan değişik çalışmalarda zeytin alanlarının potasyum bakımından beslenme durumu toprak ve yaprak analizleriyle ortaya konulmaya çalışılmıştır. Kapıdağ yarımadası zeytin alanlarında yapılan çalışmada toprakların içermiş olduğu yarayışlı potasyum içeriklerinin değişkenlik gösterdiği belirtilmiştir [21]. Araştırıcıların vermiş olduğu bilgilere göre toprakların \% 39.8'i yüksek, \% 15.2'si yeterli, \%21.4'ü orta ve \% 23.6's1 da az miktarda potasyum içermektedir. Aydın yöresinde yapılan çalışmanın yaprak analiz sonuçlarına göre zeytinliklerin \% 42'sinde potasyum eksikliği olduğu ifade edilmiştir [7]. Orhangazi yöresi Gemlik çeşidi zeytin bahçelerinde yapılan çalışmada alınan toprakların değişebilir potasyum içerikleri belirlenmiş ve farklı oranlarda potasyum içeriğine sahip oldukları görülmüştür [8]. Elde edilen sonuçlara göre toprakların \% 47.1'i düşük ve çok düşük seviyelerde değişebilir potasyum içerirken \% 52.9'unun orta ve üzeri seviyelerde potasyum içerdiği saptanmıştır. İznik ilçesinde yapılan diğer bir çalışmanın sonuçlarına göre değişebilir potasyum içerikleri 0.11-2.63 me $100 \mathrm{~g}^{-1}$ arasında değişen zeytin bahçelerinin \% 20.1'i düşük ve çok düşük, \% 24.7’si orta ve iyi, \% 55.2'si yüksek ve çok yüksek düzeyde potasyum içermektedir [28]. İçel bölgesinden alınan toprakların incelendiği çalışmada zeytinliklerin alınabilir potasyum içeriklerinin 
83-442 ppm arasında değişim gösterdiği ve \% 44'ünün yetersiz, \% 56'sının yeterli seviyede alınabilir potasyum içerdikleri bildirilmiştir [24].

Farklı bölgelerde yapılan çalışma sonuçlarına göre potasyum açısından zeytinin beslenmesi büyük farklar göstermektedir. Bu durum potasyum beslenmesinin yapılan gübreleme uygulamalarına bağlı olarak değişimler gösterdiğinin bir kanıtı olarak düşünülebilir. Çalışma sonucunda araştırmaya konu topraklarda çok büyük oranda potasyum noksanlığı belirlenmiştir. Bahçe sahipleriyle yapılan görüşmelerde potasyumlu gübrelerin hemen hemen hiç kullanılmadığı sadece bazı bahçelerde verilen kompoze gübrelerle bitkilere potasyum verildiği tespit edilmiștir. Bu durum topraklarda bu denli yüksek potasyum eksikliği çıkmasının nedeni olarak düşünülmektedir. Potasyum, zeytini halkalı leke ve diğer mantari hastalıklara karşı koruduğu gibi, kurak ve soğuğa dayanıklılık sağlayan önemli bir besindir [34]. Zeytinde ürün ve budama artıklarıyla topraktan kaldırılan besin maddesi miktarları arasındaki orana göre 0.24 birim fosfora karşlık 1.0 birim azot, 1.4 birim potasyum kaldırılmaktadır [4]. Bu yüzden potasyum eksikliği olan bahçelerde potasyum eksikliğini gidermek için ağacın yaşına ve verim durumuna göre topraktan potasyumlu gübre uygulaması yapılmalıdır [10 ve 11].

Yapılan çalışmada toprak örnekleri alınırken bahçe sahipleriyle görüşülerek bahçeye ait bazı bilgiler de alınmıştır. Ağaç başı verim ile incelenen toprak özellikleri arasındaki ilişkileri belirlemek amacıyla korelasyon analizi yapılmış ve bulunan sonuçlar Tablo 3 'te verilmiştir.

Yapılan hesaplamalar sonucunda, ağaç başı verim değerleri ağaç yaşı, toprakta elektriki iletkenlik, kireç, alınabilir fosfor içerikleri ve değişebilir potasyum değerleri arasında önemli ve pozitif yönlü ilişkiler bulunmuştur.

Tablo 3. Ağaç başı verim değerleri ile bulunan sonuçlar arasındaki ilişkilerin korelasyon katsayıları

\begin{tabular}{|c|c|}
\hline Özellikler & Ağaç başı verim $(\mathrm{kg})$ \\
\hline Ağaç yaşı & $0.50 * *$ \\
\hline Saturasyon (\%) & 0.03 \\
\hline $\mathrm{pH}$ & -0.13 \\
\hline $\mathrm{EC}_{25}\left(\mathrm{ds} \mathrm{m} \mathrm{m}^{-1}\right)$ & $0.34^{* *}$ \\
\hline $\mathrm{CaCO}_{3}(\%)$ & $0.37 * *$ \\
\hline Organik Madde (\%) & 0.18 \\
\hline Alınabilir P ( $\left.\mathrm{mg} \mathrm{kg}^{-1}\right)$ & $0.41^{* *}$ \\
\hline Değişebilir K (me $100 \mathrm{~g}^{-1}$ ) & $0.20 *$ \\
\hline
\end{tabular}

Zeytin gereksinim duyduğu su ve besin elementlerinin büyük bir bölümünü topraktan alır. Gübre uygulanmadan yetiştirilen zeytinden elde olunan ürünün gerek miktarı gerekse niteliği düşüktür. Zeytin ağaçlarının normal gelişmelerini sağlamak ve bu ağaçlardan iyi bir ürün elde etmek için yeterli miktarda fosforlu gübrelerin kullanılması gerekir. Ayrıca zeytin, azota göre topraktan çoğu zaman daha fazla potasyum alır. Bu nedenle bol ve nitelikli ürün için potasyumlu gübrelere gereksinim duyar [3]. Zeytin yapraklarının K içeriği ile ürün arasında pozitif korelasyon bulunmaktadır [35].Yapılan hesaplamalar sonucunda toprakta fosfor ve potasyum varlığındaki artışın ürün artışılla doğrusal bir ilişki göstermesi bitkinin fosfor ve potasyum gereksinimini karşılamasıyla açıklanabilir. 
Gübreler, elektriksel iletkenliği artırdığı için bitki kök bölgesinde tuzluluk yapmaktadırlar [36]. Buna göre toprağa uygulanan gübrelerin toprak tuzluluğunda bir miktar artış göstermesi beklenir. Tuzluluk değeri ile ağaç başı verim artışı arasındaki ilişkinin verilen gübrelere bağlı olarak gerçekleştiği düşünülmektedir.

\section{Sonuç}

Yapılan çalışma sonucunda en dikkat çekici değerler toprak pH'sında görülmüştür. Bahçelerin büyük çoğunluğunda toprakların zeytin için ideal toprak pH'sının altında olduğu belirlenmiştir. $\mathrm{Bu}$ nedenle özellikle bu tip bahçelerde uygulanan gübrelere dikkat etmek ve toprakta fizyolojik alkalin karakterli gübreleri tercih etmek gerekir. pH'nın çok daha düşük olduğu bahçelerde toprağın kireçlenmesi de başvurulacak tedbirlerden olmalıdır.

İncelenen bahçelerde hem fosfor hem de potasyum açısından topraklar büyük farkl1lıklar göstermektedir. Potasyum açısından toprakların büyük çoğunluğunun fakir olduğunu görüyoruz. Bu yüzden bahçelerde özellikle potasyumlu gübreleme konusunda daha dikkatli davranılması gerektiği açıkça görülmektedir. Gübreleme programları yapıllrken istenen verim ve kalitede ürün elde edebilmek için mutlaka toprak analizi yaptrılmalı ve yapılan analiz sonucuna göre gübreleme programı oluşturulmalıdır.

\section{Kaynaklar}

[1] Anonim, "FAO Statistical Databases" http://faostat.fao.org/site/567/default.aspx, Erişim Tarihi:24.03.2015, 2015a

[2] Anonim, "TÜIK" http://www.tuik.gov.tr/VeriBilgi.do?alt_id=45 Er. Tarihi:24.03.2015, 2015b

[3] Kacar B., Katkat A.V., "Gübreler ve Gübreleme Tekniği”" ViPAŞ Yayınları. No.20, s.472-489, Bursa, 1999

[4] Dikmelik Ü., "Farklı Yaşlardaki Memecik Zeytin Ağaçlarında Dane ve Budama Artıkları ile Topraktan Kaldırılan Azot, Fosfor, Potasyum Miktarlarının Saptanması Konusunda Bir Araştırma” Zeytincilik Araştırma Enstitüsü, Yayın No:31, Bornova, İzmir, 1984

[5] Klein I., Lavee S., "The Effect of Nitrogen and Potassium Fertilizers on Olive Production in Fertilizer Use and Production of Carbonhydrates and Lipids" Proceedings of the 13th Colloguim of International Potash Institue York. U.K., Bern Switzerland. Abs., 1977

[6] Uysal E., Albayrak B., Soyergin S., "Gemlik Yöresinde Yetiştirilen Zeytinlerin Beslenme Durumlarının Toprak Analizleriyle Belirlenmesi" 2. Ulusal Toprak ve Su Kaynakları Kongresi, 22-25 Kasım, s:887-895, Ankara, 2011

[7] Akıllığlu A., "Aydın Yöresi Zeytinliklerinin Beslenme Durumu" II. Ulusal Bahçe Bitkileri Kongresi Tebliğleri. Cilt I.s:711-715, Adana, 1995

[8] Albayrak B., Uysal E., Soyergin S., "Orhangazi Yöresinde Gemlik Çeşidi Zeytin Yetiştirilen Toprakların Verimlilik Durumlarının İncelenmesi” 5. Ulusal Bitki Besleme ve Gübre Kongresi 15-17 Eylül, Ege Üniversitesi Ziraat Fakültesi Dergisi Özel Sayı Bildiriler Kitabı s. 430-434. İzmir, 2010

[9] Soyergin S., Katkat A.V., "Bursa Yöresi Gemlik Çeşidi Zeytinlerin Yaprak Meyvelerinde Bor İçeriğinin Mevsimsel Değişimi” Tr.J. of Agricultural and Forestry, 18:515-520, 1994. 
[10] Canözer Ö., “Zeytin Gübreleme Tekniği” Zeytincilik Araştırma Enstitüsü Yayınları No:28, Bilgehan Basımevi, s:1-24, Bornova, İzmir, 1983

[11] Katkat A.V., “Zeytin Gübreleme Tekniği, Zeytin Tarımı ve Sofralık Zeytin Üretimi” Marmara Birlik Yayınları 2:19-27, Bursa. 1994

[12] İrget M. E., Kılıç C.C., Bayaz M., Özer K., “Azotlu Gübrelemenin Zeytinde (Olea europaea. cv. Memeci) Verim ve Kaliteye Etkisi” ADÜ Ziraat Fakültesi Dergisi 4 (1-2), 27-33, 2007

[13] Karabulut A., Elbaşı F., Ustaoğlu S., Yatman D., “Türkiye büyük toprak grubu haritası" Tarımsal Araştırmalar ve Politikalar Genel Müdürlüğü Toprak Gübre ve Su Kaynakları Merkez Araştırma Enstitüsü Müdürlüğü, Mekanizasyon ve Bilişim Teknolojileri Bölümü, Ankara, 2011

[14] Kacar B., “Toprak Analizleri” Nobel Bilim ve Araştırma Merkezi Yayın No:44 467 s, Ankara, 2009

[15] Gedikoğlu İ., "Laboratuvar Analizlerinin Gübre Önerilerinde Kullanılması ve Halen Kullanılan Kriterler” T.K.B. Köy Hiz. Gn. Müd. Yayınları, Genel Yayın No: 57, Teknik Yayın No: 13, Şanlıurfa, 1990

[16] Anonim, “The Analysis of Agricultural Materials” Second Edition Ministry of Agri. Fisheries and Food RB 427, Replaces Technical Bulletin 27, p. 226., 1981

[17] Çağlar K.Ö., “Toprak Bilgisi” A.Ü.Z.F. Yayınları, Yayın No:10. s.286, 1958

[18] Jackson M.L., “Soil Chemical Analysis” Prentice Hall. Inc. 183, New York, 1962

[19] Olsen S.R., Cole V., Watanabe F.S., Dean L.A, "Estimation of Available Phosphorus in Soils by Extraction with Sodium Bicarbonate” U.S.D.A. Circular no. 939. Washington D.C., 1954

[20] Anonim, "Soil and Plant Testing and Analysis as a Basis of Fertilizer Recommendations" F.A.O., Soils Bulletin, 38/2, p.95., 1980

[21] Sağlam M.T., Bellitürk K., Hazinedar N., Danışman F., "Kapıdağ Yarımadası Zeytinliklerinin Beslenme Durumu” Selçuk Üniversitesi Ziraat Fakültesi Dergisi 22 (44), 118-123, Konya, 2008

[22] Çolakoğlu H., “Gübre ve Gübreleme” Ege Üniversitesi Zir. Fak. Teksir No:17, Bornova, İzmir, 1985

[23] Eyüpoğlu F., “Türkiye Topraklarının Verimlilik Durumu” Toprak ve Gübre Araştırma Enstitüsü Yayınları, Genel Yayın No:220, Teknik Yayın No:T-67, Ankara, 1999

[24] Doran İ., Aydın R., “İçel Yöresi Zeytinliklerinin Beslenme Durumunun Tespiti” Anadolu, J. of AARI 9 (1), 105-130, İzmir, 1999

[25] Fink A., “Introduction and Practical Guide to Crop Fertilization” Fertilizers and Fertilization. Verlag Chemie GmbH, Weinheim 438 s., 1982

[26] Dellavalle N.B., "Determination of Specific Conductance in Supertanat 1:2.5 Soil:Water Solution In Handbook on Reference Methods for Soil Analysis” Soil and Plant Analysis Council. Inc. Athens, GA., 1992

[27] Zabunoğlu S., Hatipoğlu F., Yenicesu İ., "Bursa İlinde Yetiştirilen Sofralık Gemlik Çeşidi Zeytin Ağaçlarının Makro ve Mikro Besin Maddeleri Durumu” A.Ü.Z.F. Yay. No: 792, Ankara, 1981 
[28] Uysal E., Albayrak B., Soyergin S., "İznik Yöresinde Yetiştirilen Zeytinlerin Beslenme Durumlarının Toprak Analizleriyle Belirlenmesi” Türkiye VI. Ulusal Bahçe Bitkileri Kongresi, 4-8 Ekim, Bildiriler Kitab1, s. 365-374, Şanlıurfa, 2011

[29] Güçdemir İ.H, “Türkiye Gübre ve Gübreleme Rehberi” T.C. Tarım ve Köyişleri Bakanlı̆̆ Tarımsal Araştırmalar Genel Müdürlüğü Toprak ve Gübre Araştırma Enstitüsü Müdürlüğü Yayınları, Genel Yayın No: 231, Teknik Yayınlar No. T. 69, Ankara, 2006

[30] Özbek N., “Meyve Ağaçlarının Gübrelenmesi” T.O.K.B., Ankara, 1981

[31] Llamas J.F., "Basis of Fertilization in Olive Cultuvation and the Olive Trees Vegetative Cycle and Nutritional Needs" International Course on Fertilization and Intensitication of Olive Cultivation. UNDP-FAO, Cordoba-Spain, 1984

[32] Özölçüm Ü., Üner K., “Aydın Yöresinde Ticaret Gübrelerinin Zeytin Üretimine ve Yapraktaki Bazı Besin Maddeleri Kapsamına Etkileri” Toprak Su A.E. Yay. No: 115, Menemen-İzmir, 1985

[33] Pizer N.H., “Some Advisory Aspect” Soil Potassium and Magnesium. Tech. Bull. No.14:184, 1967

[34] Genç Ç., Moltay İ., Soyergin S., Fidan A.E., Sütçü, A., "Marmara Bölgesi Sofralık Zeytinlerinin Beslenme Durumu” Bahçe Dergisi, 20:1-2, Yalova, 1991

[35] Fox R.L., Aydeniz A., Kacar B., "Soil and Tissue Tests for Predicting Oive Yields in Turkey" The Empire Journal of Experimental Agriculture, 32(125):84-91, 1964

[36] Çetin Ö., Tolay İ., “Tuzluluk ve Gübre İlişkisi” Fertigasyon: Sulama ile Birlikte Gübreleme Hasad Yayıncılık, s:38-39., İstanbul, 2009 